\title{
LABOUR AND EMPLOYMENT IN A HIGHLY INDUSTRIALIZED STATE, GUJARAT
}

\section{Dr. Sonal S. Yadav}

\section{KEY WORDS:}

Labour. Employment, Micro and Small Enterprises, informal sector

JEL Classification: J21, E24, L11, 017

\begin{abstract}
The present study deals with the problems related to labour and employment in the Micro and Small Enterprises (MSEs) of Gujarat. It is worth mentioning here that although, Gujarat is a home to successful mobilization of Informal workers, and the MSEs of Gujarat has been facing a problem of labour shortage for a decade now. The study focuses on Gujarat because it is a highly industrialized state. More than 10 percent of country's industries are located in Gujarat and contribute more than 7.5 percent to India's GDP. It has been observed that, after the implementation of Mahatma Gandhi National Rural Employment Guarantee Act (MGNAREGA), the problem has increased. To understand the problems of labour, a field study and in-depth interview with employers and employees of Micro and Small Engineering Enterprises was conducted in three districts of Gujarat namely Ahmedabad, Vadodara and Bhavnagar during May-June 2013-14. The study proposes to examine the problems of laborers along with employment conditions in MSEs. It was found that there is emergence of absenteeism and carelessness on the part of labour on one hand and lack of security and dignity on the other
\end{abstract}


hand. To deal with such situation, existing MSEs are shedding excess labour by adopting technology to survive in the competitive market and to increase the labour productivity.

\section{The objectives of the study}

1. To understand the reasons behind labour shortage and problems of informal labor after the reforms.

2. To examine employment conditions and employers' preference for investment in the technology after the reforms.

\section{Data Source and Methodology}

The study is based on primary data which is collected by conducting a field survey in Gujarat by using questionnaire/interview schedule. Micro and Small Engineering Industries (MSEIs) located in the Gujarat Industrial Development Corporation (GIDC) estates were selected for the study. A list of MSEs was prepared from the directory of GIDC units. Based on the list, 70 employers and 280 employees of MSEIs were selected for the survey.

\section{Development of Questionnaire and Collection of Data}

To develop questionnaire/ interview schedule and to identify the field level problems a pilot study was conducted. The employers and employees of MSEIs were contacted during the pilot study. Focus Group Discussions (FGD) and In-depth Interviews were conducted with the employers and the employees to identify the problems. After lots of deliberations and discussions, the questionnaire was prepared and modified considering the comments and the suggestions given by the employers and the employees of the randomly selected MSEIs.

\section{Introduction}

The Indian labour market is characterized by predominance of informal employment with more than 90 percent of workforce working as self-employed and casual workers. Particularly, after the economic reforms, the share of unorganized sector employment has increased. This sector contributes about 50 percent of the national income ${ }^{1}$.

\footnotetext{
${ }^{1}$ Report of the Committee on Unorganized Sector Statistics, National Statistical Commission, Feb. 2012.
} 
The study by Sengupta 2009, covering the period from 1999-2000 to 2004-2005, found considerable increase in informal employment in the formal sectors. As per NSSO data, in 201112 , informal employment in both organized and unorganized manufacturing sector has increased as compared to 2004-05. The worrying trend is the increasing extent of informal employment even in the organized sector (Mundle 1992, Bhattacharya and Mitra 1993, Bhandari and Heshmati 2006, Maiti 2009).

Thus, during the post reform period, there has been clear evidence of contractualisation and informalisation in Indian labour market which ignores labour regulations related to job security. This was a kind of relatively insecure employment at lower wage rates and there is limited database available that cover the unorganized sector. To address and overcome the challenges, Micro and Small Enterprises (MSEs) must be encouraged to register.

\section{Informal Employment: India and other Economies}

In India, the vast majority of workers are employed in the unorganized sector where jobs are insecure and uncertain. This form of employment is not covered by legislative policy measures and there is no control over the hours of work and wage rate. Given the large size of unorganized sector and unorganized employment in India, the government set up the National Commission for Enterprises in Unorganized Sector (NCEUS) in September 2004. The estimates given by the NCEUS revealed that out of total unorganized workers, only six per cent workers were covered under statutory social security while 86 percent of workers were without any kind of social security (NCEUS 2007).

The emerging economies and South Asian countries are experiencing expansion in informal sector and employment therein (ILO 1996). After 1980s, due to different domestic policies and rise in the demand for educated labour, there was increase in the wage gap between more and less educated workers in most of countries. Furthermore, technological change caused a skill bias which was responsible for added wage inequality in the United States, United Kingdom, 
Australia and Japan, while these trends were less extreme in Canada. (Davis 1992, Gottschalk and Smeeding, 1997; Schultz, 1998b cited in article by T. P. Schultz Page 304).

Three major studies based on primary survey about labour flexibility in India conducted by Sudha Deshpande et al. 1998, Sharma and Sasikumar 1996 and Lalit Deshpande et al. 2004 found that irrespective of the size of firm, there was an increase in employment mainly by increase in the share of non-permanent workers i.e. contract workers.

Various studies found that rigidities in labour market, poor skill levels and increasing competition from imports were the main reasons behind creation of informal employment and decline in formal employment opportunities in the manufacturing sector (Srija and Shirke 2014). However, the calculation based on the unit level data of NSSO Employment and Unemployment Survey 2011-12, found that informal employment in the manufacturing sector is high even in the state with high Labour Reform Index (LRI) ${ }^{2}$. For instance, Gujarat with LRI (value 53), Uttar Pradesh (with LRI value 58) and Andhra Pradesh (with LRI value 56) are the state where the stringency of labour regulation has been lowered however the informal jobs are very high in the manufacturing sector. This gave rise to various issues related to decent conditions of work such as paid leave, pension, bonus, medical support, health insurance, maternity leave benefits, compensation against accident, etc. However, such rights are nearly nonexistent, particularly in the unorganized sector.

Thus, irrespective of the labour reforms, the extent of informal employment in the manufacturing sector in Gujarat, Uttar Pradesh and Andhra Pradesh is very high. This shows that labour reform alone will not help in reducing the level of informal employment but the rise in the educational level will also help in this regard as the preference for formal job will increase with increase in the level of education.

\footnotetext{
${ }^{2}$ Labour Reform Index is taken from Sean Dougherty article "Labour Regulation and Employment Dynamics at State Level in India" (2008). The index may not capture the labour reform regulations that took place after 2008. The index reflects the extent to which procedural changes have reduced transaction cost, through limiting the cost of regulations, providing greater clarity in their application or simplifying compliance procedure. Lower value (on the scale of 1-100) index implies the number of reforms carried out by states are few.
} 


\section{Reasons Behind Labour Shortage in MSEs in Gujarat}

\section{Low wages to Informal Workers and MGNAREGS:}

National Sample Survey (NSS) on "Key Indicators of Employment and Unemployment in India" was conducted to collect information from June 2009 and June 2010. The report stated that in Gujarat, the average wages offered to the casual workers were lowest while the labour force participation was the highest with 87.5 percent of males in the economically active age group of 15-59 years. This may be due to the fact that conducive industrial environment in Gujarat attracted relatively higher number of casual workers including migrants from other parts of India. Because of relatively higher supply of labour (local and migrants) in the state, there was less pressure on the employers to pay a higher wages. Moreover, these workers remain absent during festival season. As a consequence, factories in Gujarat have been experiencing shortage of labour especially during the festival months.

In urban areas, the labour shortage is felt due to fast development of infrastructure in the rural areas and rural employment scheme like MGNAREGS, which has also created more employment opportunities in the villages. This has created an adverse effect on urban manufacturing sector in terms of shortage of workers. It has also produced a substantial impact on rural employment and rural wages. With the payment of better wages under MGNREGA program, the bargaining power of poor or those without any support has gone up. Large numbers of low paid workers were attracted to MGNREGS because they started getting fair wages under this scheme, which led to increase in the rural employment and rural wages, which to some extent have reduced migration from rural to urban areas and thus created shortage of labour in the urban Small Scale Industries (SSIs) at some places.

\section{Job Opportunities and Higher Wages Offered in Construction Sector}

An increase in the job opportunities and higher wages offered in alternative sectors like construction and service activities has further aggravated the problem of labour shortage 
in manufacturing sector. With this trend, manufacturing sector may be in a downward spiral, while the construction sector is expanding. The employment opportunities in the construction sector has increased from 17.5 million to 44.2 million in 2009-10. There is also an increase in the wage gap among the workers of urban Gujarat and urban India (NSSO 2011-12). Hirway and Shah 2011 in their study found that the rapid growth in the State Domestic Product (SDP) in Gujarat is accompanied by slow rise in wage rate. The study discusses that gains in productivity has not been shared among the industrial workers. The study also suggests that labor-intensive and equitable growth in the state can be promoted by providing a just share to labour.

Moreover, due to rising cost of living in urban areas, the workers are demanding higher wages while most of the employers in the SSI units are unable fulfill due to rising cost of raw material and decrease in the profitability of the enterprise. Not only that, the productivity of workers has also witnessed a downward trend. To solve the problems of low productivity and labour shortage, the decisions of employers have started tilting towards the use of technology in the SSIs. However, due to the inadequacy and high cost of credit, micro industries often find it difficult to invest in latest technology.

Another cause of concern is that local labour has been shifting from MSEIs to construction work that offers almost double the wage than that of MSEIs. On an average a laborer gets ₹ 100 to ₹ 259 per day in any MSEIs but in construction work they get between ₹ 300 to ₹ 500 per day (Business Standard, April 16, 2011). Moreover, construction sectors provide job opportunity to women workers also. Thus, it helps in increasing earning level of family because husband and wife both contribute towards the earning of the family.

\section{Preference for Capital Intensive Technology}

A study by Dhas and Helen 2008 found that in the SSIs which were mostly in the unorganized sector, labour productivity had fallen compared to capital productivity, as a result, method of production changed from labour intensive to capital intensive method of 
production. Thus, capital intensity was a major driver of labour productivity in both organized and unorganized manufacturing sector. Immediately after reforms i.e. during 1994 to 2001, the capital-labour ratio registered a faster growth compared to 2001 to 2005.

The contribution of manufacturing sector in Gross State Domestic Product (GSDP) is more than 28 percent. The state aims to create employment opportunities for skilled and unskilled workforce by promoting labour intensive industries. However, over a period of time the preference for desk job has increased compared to manual job which is also one of the reasons for labour shortage in the manufacturing sector.

\section{Problems of Informal Labour}

\section{Poor Working Conditions}

The unorganized sector workers suffer from extremely bad working condition with subsistence level of wages, unstable employment contracts and little or no provision for income and social security benefits while the organized sector workers enjoy improved working condition, higher wages and job security. Thus, there is a vast difference in income and efficiency characteristic among the organized and unorganized manufacturing sector workers.

\section{Lower Level of Skills and Education}

One of the characteristic features of unorganized sector workers is their lower level of skills, knowledge, awareness and education, which makes the absorption of new and existing technology difficult. Thus, higher level of education makes powerful contributions to technology creation and diffusion. The average schooling attained by unorganized sector worker was significantly lower (illiterate or below primary level) than the organized sector worker (NSSO 2004-05). 
According to Dutta $2005^{3}$, education served to narrow inequality among regular workers while age, industry affiliation and selection were consistently the most important sources of widening inequality.

In case of Gujarat, about 87 percent of the MSEIs faced labour shortage due to which employers were unable to meet production targets. Most of the employers (85 percent) felt that because of non-availability of skilled and experienced labour, employers were unable to upgrade technology.

\section{Absenteeism and Irresponsible Working Style}

The most common problem of informal labour is high level of absenteeism which can be solved by increasing the wage rate and by providing them residential facilities near to their workplace. There is also a need to build hospitals for attending industrial accidents besides providing regular health check-ups.

In Gujarat, it is observed that when workers go home, some of them do not return to resume work in the factory, as they generally find work mainly in their own village whereas some return after considerable delay. In their absence, employers have to hire contract labourers to get the work done within the stipulated time period. Thus, the level of absenteeism especially during the festival time is very high among them. Lack of education, training and work for survival only could be the reasons behind their irresponsible working style.

The study by Drago and Wooden 1992, have analyzed causes of absenteeism from work in Australia, Canada, New Zealand, and the United States using data from the survey. The study found that wage rate, job satisfaction, workgroup cohesion, status of employment, gender, unemployment rate among others were determinants of absenteeism

${ }^{3}$ Dutta, P. V., (2005), Accounting for Wage Inequality in India, PRUS Working Paper no. 29 
at workplace. SSIs in India must take care of all these determinants to reduce absenteeism at workplace.

\section{Conclusion}

The study clearly states that the labour market is not perfectly elastic as finding labour is very difficult task. Neither the employers have full information about job seeking workers nor do the unemployed workers know about job vacancies in the small enterprises. There is huge gap between demand and supply of skilled and unskilled labour. In case of Gujarat, the actual availability of labour (both skilled and unskilled) is 40 percent less than the required one. Thus, on one hand, the demand of skilled labour has increased at the faster rate with the growth and expansion of the enterprise while on the other hand skill shortage has raised concern among the employers. Looking at this gap, MSEs situated in urban areas have slowly started investing in technology in order to increase productivity which will help in increasing total production and employment in the long run. However, in rural enterprises, investment in technology was less compared to urban enterprises because of high maintenance and depreciation costs per unit of output of the machinery. Moreover, non-availability of technicians and skilled manpower further added to an increase in the cost of production. Therefore, the technical institutes must take into consideration the requirement of the industry while designing the syllabus for imparting education and training to the students, so that they could be absorbed easily in the industries. This will strengthen the bargaining power of workers, along with increasing the productivity of capital. 


\section{$\underline{\text { References }}$}

Bhandari, A. K., \& Heshmati, A. (2006). Wage inequality and job insecurity among permanent and contract workers in India: Evidence from organized manufacturing industries.

Bhattacharya, B. B., \& Mitra, A. (1993). Employment and structural adjustment: A look at 1991 census data. Economic and Political Weekly, 1989-1995.

Cranford, C. J., Vosko, L. F., \& Zukewich, N. (2003). Precarious employment in the Canadian labour market: A statistical portrait. Just labour, 3.

Dhas, A. C., \& Helen, M. J. (2008). Impact of Globalisation and Economic Reforms on Employment in India. MPRA Paper No. 9597. Retrieved from

http://mpra.ub.unimuenchen.de/9597/

Deshpande, S., Standing, G., \& Deshpande, L. (1998). Labour Flexibility in a Third World Metropolis: A Case Study of Bombay. Indian Society of Labour Economics and Commonwealth Publishers, New Delhi.

Deshpande et. al, (2004). Liberalization and Labour: Labour Flexibility in Indian Manufacturing. Institute for Human Development, New Delhi.

Drago, R., \& Wooden, M. (1992). The determinants of labor absence: Economic factors and workgroup norms across countries. Industrial \& Labor Relations Review, 45(4), 764-778 Dutta, P. V., (2005), Accounting for Wage Inequality in India, PRUS Working Paper no. 29

Government of India. (2014). NSSO (2014b), 68th Round (July 2011-June 2012), Informal Sector and Conditions of Employment in India, NSS Report No 557 (68/10/2), Ministry of Statistics and Programme Implementation. 
Government of India. (2001). Report of the Task Force on Employment Opportunities. New Delhi.

Government of India. (2003). Report of Second National Commission on Labour, p. Chapter 1, page 12 .

Government of India. (2012). Report of the Committee on Unorganized Sector Statistics. National Statistical Commission

Hirway, I., \& Shah, N. (2011). Labour and employment under globalisation: The case of Gujarat. Economic \& Political Weekly, 46(22), 57.

ILO-ARTEP. (1993) India: Employment, Poverty and Labour Policies.

Maiti, D. (2009). Institutions, Networks and Industrialisation: Field level evidence of fragmentation and flexibility from India. IPPG Discussion Papers, http://www.ippg.org.uk/papers/dp26.pdf

Mundle, S. (1992). The Employment Effects of Stabilisation and Related Policy Changes in India, 1991-92 to 1993-94. Indian Journal of Labour Economics, 35(2), 227-37.

National Commission for Enterprises in Unorganised Sector. (2008). Contribution of the unorganized sector to GDP. Report of the Sub Committee of a NCEUS Task Force (Working Paper No. 2). www.nceus.gov.in

Schultz, T. P. (1999). Labor Market Reforms: Issues, Evidence and Prospects (No. 802). Center Discussion Paper.

Sengupta, A. K. (2009). The Challenge of Employment in India: An Informal Economy Perspective, Report of the National Commission for Enterprises in the Unorganised Sector. Government of India Volumes 1 and 2Academic Foundation, New Delhi. 
Sharma, A., \& Sasikumar, S. K. (1996). Structural Adjustment and Labour. VV Giri National Labour Institute, NOIDA (mimeo).

Srija A. \& Shirke, S.V. (2014). An Analysis of the Informal Labour Market in India, Economy Matters 19(9), 40-46.

Report of the Committee on Unorganized Sector Statistics, National Statistical Commission, Feb. 2012.

\section{Dr. Sonal S. Yadav}

Assistant Professor, Economics and Public Policy Area

Ahmedabad University, Ahmedabad 380 009, India

(M) 94270 49286, Email-sonal.yadav@ahduni.edu.in, sonalyadav7@gmail.com 